\title{
Kandungan dan Aktivitas Antioksidan pada Rumput Laut Merah
}

\author{
Rafaela E. M. Loho, ${ }^{1}$ Murniati Tiho, ${ }^{2}$ Youla A. Assa ${ }^{2}$
}

\author{
1Program Studi Pendidikan Dokter Fakultas Kedokteran Universitas Sam Ratulangi, Manado, \\ Indonesia. \\ ${ }^{2}$ Bagian Biokimia Fakultas Kedokteran Universitas Sam Ratulangi Manado, Indonesia \\ Email: rafaella85loho@gmail.com
}

\begin{abstract}
The imbalance between free radicals and endogenous antioxidants produced by the body can cause cell damage resulting in various diseases such as cancer, heart disease, cataracts, premature aging, and other degenerative diseases. Antioxidants that can capture and neutralize free radicals are needed to cease further reactions causing oxidative stress. Therefore, the consumption of natural antioxidants which are abundant in plants needs to be increased. Red seaweed, known as red algae, has a lot of biological activity compared to other types of seaweed. This study was aimed to determine the content and antioxidant activity of red seaweed (Eucheuma cottonii). This was a literature review study using three databases: Pubmed, ClinicalKey, and Google Scholar. The keywords used were Antioxidant AND Rhodophyta AND Gracilaria sp AND Eucheuma Cottonii. After screening and feasibility assessed we obtained 10 journals using experimental method to evaluate the total phenol content and antioxidant activity of Gracilaria sp. and Eucheuma cottonii. The results showed that red seaweed contained antioxidant compounds such as phenolics and flavonoids that had high antioxidant activity. In conclusion, red seaweed contains compounds with high antioxidant activity such as phenolics and flavonoids.
\end{abstract}

Keywords: antioxidant; red seaweed; phenolic; flavonoid

\begin{abstract}
Abstrak: Ketidakseimbangan jumlah radikal bebas dengan jumlah antioksidan endogen yang diproduksi tubuh dapat menyebabkan terjadinya kerusakan sel yang dapat menimbulkan berbagai penyakit seperti kanker, jantung, katarak, penuaan dini, serta penyakit degeneratif lainnya. Tubuh memerlukan asupan senyawa antioksidan yang mampu menangkap dan menetralisir radikal bebas tersebut, sehingga reaksi lanjutan yang menyebabkan terjadinya stres oksidatif dapat berhenti. Konsumsi antioksidan alami yang banyak terkandung pada tumbuhan perlu ditingkatkan. Rumput laut merah yang dikenal sebagai alga merah merupakan jenis rumput laut yang banyak memiliki aktivitas biologi dibandingkan dengan jenis rumput laut lainnya. Penelitian ini bertujuan untuk melihat kandungan dan aktivitas antioksidan pada rumput laut merah (Eucheuma cottonii). Jenis penelitian ialah suatu literature review dengan pencarian data menggunakan 3 database yaitu PubMed, ClinicalKey dan Google Scholar. Kata kunci yang digunakan ialah Antioksidan AND Rhodophyta AND Gracilaria sp AND Eucheuma Cottonii. Setelah skrining serta uji kelayakan didapatkan 10 jurnal dengan metode penelitian eksperimental yang menguji kandungan total fenol dan aktivitas antioksidan pada Gracilaria sp. dan Eucheuma cottonii. Hasil kajian menunjukkan adanya senyawa yang berperan sebagai antioksidan seperti fenolik dan flavonoid yang memiliki aktivitas antioksidan tinggi. Simpulan penelitian ini ialah rumput laut merah mengandung senyawa yang memiliki aktivitas antioksidan yang tinggi seperti fenolik dan flavonoid.
\end{abstract}

Kata kunci: antioksidan; rumput laut merah; fenolik; flavonoid

\section{PENDAHULUAN:}

Ketidakseimbangan jumlah radikal bebas dengan jumlah antioksidan endogen yang diproduksi tubuh, dapat menyebabkan terjadinya kerusakan sel yang dapat menimbulkan berbagai penyakit seperti kanker, 
jantung, katarak, penuaan dini, serta penyakit degeneratif lainnya. Adanya radikal bebas tersebut, didukung oleh faktor dari luar tubuh yang mengalami peningkatan seperti polutan udara, radiasi, zat-zat kimia karsinogenik, asap rokok, bakteri, virus, dan efek obat (obat anastesi dan pestisida). Hal ini menyebabkan tubuh memerlukan asupan yang mengandung senyawa antioksidan yang mampu menangkap dan menetralisir radikal bebas tersebut sehingga reaksi lanjutan yang menyebabkan terjadinya stres oksidatif dapat berhenti dan kerusakan sel dapat dihindari atau induksi suatu penyakit dapat dihentikan. ${ }^{1}$

Antioksidan dapat berupa antioksidan alami seperti yang terkandung dalam berbagai tumbuhan maupun antioksidan sintetis yang sengaja ditambahkan (zat aditif) pada makanan dan minuman yang dikonsumsi. Penggunaan atau pemaparan antioksidan sintetis dalam waktu yang cukup lama bukan merupakan antioksidan yang baik karena dapat menimbulkan efek samping berupa peradangan sampai kerusakan hati dan meningkatkan risiko penyakit karsinogenesis. ${ }^{2}$ Oleh karena itu konsumsi antioksidan alami yang terdapat dalam buah, sayur, bunga, dan bagian lain dari tumbuhan perlu ditingkatkan. Rumput laut memungkinkan untuk digunakan sebagai sumber antioksidan karena memiliki kemampuan untuk menghambat peroksidasi lemak dan dapat mengurangi beberapa efek dari radikal bebas. ${ }^{3}$

Rumput laut merupakan salah satu sumber daya hayati yang sangat melimpah di perairan Indonesia. Van Bosse melaporkan bahwa Indonesia memiliki kurang lebih 555 jenis dari 8.642 spesies rumput laut yang terdapat di dunia. Dengan kata lain, perairan Indonesia sebagai wilayah tropis memiliki sumber daya plasma nutfah rumput laut sebesar $6,42 \%$ dari total biodiversitas rumput laut dunia. ${ }^{4,5}$ Rumput laut dari kelas alga merah (Rhodophyta) menempati urutan terbanyak dari jumlah jenis di perairan laut Indonesia yaitu sekitar 452 jenis. ${ }^{6}$

Rumput laut dari kelas alga merah mengandung senyawa bioaktif sehingga memiliki potensi untuk dikembangkan sebagai bahan nutraseutikal. ${ }^{7}$ Rumput laut memiliki kemampuan sebagai antioksidan, imunostimulan, dan aktivitas antibakteri. ${ }^{8}$ Rumput laut merah yang dikenal sebagai alga merah merupakan jenis rumput laut yang banyak memiliki aktivitas biologi dibandingkan dengan jenis rumput laut lainnya. ${ }^{9}$

Salah satu senyawa yang berperan sebagai antioksidan dari rumput laut yaitu senyawa fenolik. Senyawa ini merupakan kelompok senyawa terbesar yang berperan sebagai antioksidan alami pada tumbuhan dan juga banyak terdapat pada hampir semua jenis rumput laut. ${ }^{10}$ Senyawa fenolik dapat berfungsi sebagai anti radiasi sinar ultra violet dikarenakan senyawa ini memiliki ikatan yang saling berkonjungasi dalam inti benzena sehingga akan terjadi resonansi dengan cara transfer elektron. ${ }^{11}$ Penelitian Kurniawati ${ }^{3}$ mendapatkan kandungan fenol tertinggi yaitu 7,16 ppm dengan pelarut metanol $96 \%$ pada waktu perendaman selama 48 jam pada jenis Gracilaria sp.

Flavonoid merupakan golongan terbesar senyawa fenolik yang memiliki gugus kromofor. Gugus tersebut memiliki kemampuan untuk menyerap gelombang sinar UV. ${ }^{11}$ Yanuarti et al $^{10}$ mendapatkan bahwa total flavonoid dari ekstrak $T$. conoides (157,16 mg QE/g) dan E. cottonii $(35,18 \mathrm{mg}$ QE/g) dapat menjadi sumber penting antioksidan karena kandungan flavonoid yang diperoleh dari kedua ekstrak tersebut cukup tinggi sehingga senyawa flavonoid dapat berperan sebagai antioksidan.

Berdasarkan latar belakang ini maka penulis tertarik untuk mengetahui kandungan fenolik, flavonoid dan aktivitas antioksidan pada rumput laut merah dan mengidentifikasi senyawa fenolik dengan metode total phenolic content (TPC) dan aktivitas antioksidan dengan metode 1,1diphenyl-2-picrylhydrazyl (DPPH).

\section{METODE PENELITIAN}

Penelitian ini menggunakan metode deskriptif, yang berbentuk suatu literature review. Identifikasi, evaluasi dan interpretasi dilakukan terhadap semua hasil penelitian tertentu, berdasarkan topik yang 
telah dipilih untuk menjadi pokok bahasan.

Data yang digunakan dalam penelitian yaitu data sekunder yang diperoleh dari tiga database yaitu Pubmed, Clinical Key dan Google Scholar. Kata kunci yang digunakan ialah Antioksidan AND Rhodophyta AND Gracilaria sp AND Eucheuma Cottonii.

\section{HASIL PENELITIAN:}

Hasil pencarian literatur dilakukan melalui Pubmed, Clinical Key dan Google Scholar, mendapatkan artikel sebanyak 17 dengan menggunakan Pubmed, 2.392 dengan menggunakan Clinical Key, dan 9.870 dengan menggunakan Google Scholar $(\mathrm{n}=12.297)$. Berdasarkan kriteria inklusi dan eksklusi, serta hasil seleksi akhir didapatkan 10 literatur yang memenuhi kriteria dan lolos tahap seleksi; kesemuanya menggunakan metode eksperimental (Tabel 1).

Tabel 1. Keterangan studi yang dimuat pada literatur

\begin{tabular}{|c|c|c|}
\hline $\begin{array}{l}\text { Penulis, } \\
\text { tahun }\end{array}$ & Population & Intervention/Comparator \\
\hline Foon, $2013^{11}$ & $\begin{array}{l}\text { Eucheuma } \\
\text { cottonii } \\
\text { diambil dari } \\
\text { Pulau Besar, } \\
\text { Mersing }\end{array}$ & $\begin{array}{l}\text { Dilakukan dua metode ekstraksi: (i) meto- } \\
\text { de konvensional: } 10 \mathrm{~g} \text { rumput laut dicam- } \\
\text { pur } 10 \mathrm{ml} \text { metanol, diaduk dengan shaker } \\
(120 \mathrm{rpm}) \text { dalam suhu kamar selama } 72 \\
\text { jam. Difilter dengan Whatman paper no.1, } \\
\text { pelarut dihilangkan dengan rotary evapora- } \\
\text { tor suhu } 40^{\circ} \mathrm{C} \text {; (ii) metode Soxhlet: } 20 \mathrm{~g} \\
\text { rumput laut ditaruh dalam sohxlet aspa- } \\
\text { ratus, diekstraksi dengan } 200 \mathrm{ml} \text { metanol } \\
\text { suhu } 60^{\circ} \mathrm{C} \text { selama } 12 \text { siklus berturut. } \\
\text { Diuapkan pada rotary evaporator suhu } 40^{\circ} \mathrm{C}\end{array}$ \\
\hline $\begin{array}{l}\text { Wardhani, } \\
2013^{12}\end{array}$ & $\begin{array}{l}\text { E. cottonii se- } \\
\text { gar diambil } \\
\text { dari Kepulau- } \\
\text { an Karimun } \\
\text { jawa }\end{array}$ & $\begin{array}{l}\text { Dilakukan ekstraksi dengan ultrasonik } \\
\text { (UAE). Satu gram E. Cottonii dicampur } \\
\text { dengan } 10 \mathrm{ml} \text { metanol dalam labu ukur dan } \\
\text { ditutup alumunium foil. Labu ukur ditaruh } \\
\text { dalam penangas ultrasonik. Ekstraksi diatur } \\
\text { dalam berbagai suhu }\left(35^{\circ} \mathrm{C}-60^{\circ} \mathrm{C}\right) \text {, waktu } \\
(10-45 \text { menit) dan rasio cair-padat ( } 3: 1- \\
10: 1) \text {. }\end{array}$ \\
\hline
\end{tabular}

Chang dan Eucheuma Teo, $2016^{13}$ cottonii yang diambil dari daerah pesisir di Sabah, Malaysia

Muawanah, $2016^{14}$
Rumput laut dicuci dengan air bersih dan dikeringkan pada suhu $40^{\circ} \mathrm{C}$ selama 36 jam. Kemudian rumput laut (10 g) diekstraksi dengan $100 \mathrm{ml}$ Metanol pada suhu kamar selama 72 jam. Sampel kemudian difilter dengan Whatman paper no.l dan pelarut dihilangkan dalam vakum pada $40^{\circ} \mathrm{C}$ menggunakan rotary evaporator. Ekstrak diliofilisasi semalaman menggunakan freeze-dryer. Ekstrak bentuk bubuk disimpan dalam pendingin $-20^{\circ} \mathrm{C}$.

E.cottonii di- Ekstrak polisakarida dari E. cottonii dibuat cuci dengan dengan cara ekstraksi dengan air selama 1 air bersih, dikeringkan pada sinar matahari selama 5 hari dan oven $60^{\circ} \mathrm{C}$ selama 3 jam
TPC pada E. Cottonii dengan konvensional ekstraksi didapatkan $8.71 \pm 0.09 \mathrm{mg}$ GAE/g dan sohxlet ekstraksi didapa-tkan $9.04 \pm 0.05 \mathrm{mg}$ GAE/g. Aktivitas antioksidan dengan metode DPPH didapatkan pada sohxlet ekstraksi lebih tinggi $(31.44 \pm 0.08 \mathrm{mg} / \mathrm{ml})$ daripada konvensional ekstraksi $(32.74 \pm 0.16 \mathrm{mg} / \mathrm{ml})$ walaupun tidak berbeda secara signifikan

TPC dilakukan pada suhu yang berbeda dan ditemukan nilai tertinggi pada suhu $55^{\circ} \mathrm{C}$ pada UAE yaitu $3.88 \mathrm{mg}$ GAE/g DW. Pada variasi waktu didapatkan nilai TPC tertinggi (4.2 mg GAE/g DW) pada menit 35 saat ekstraksi. Pada rasio pelarutpadat ditemukan TPC tertinggi (4.440 mg GAE/g DW) pada perbandingan 3:1. Pada uji aktivitas antioksidan dinilai pada perbandingan 3:1 didapatkan aktivitas antioksidan $69 \%$.

Hasil penelitian menunjukkan Arsen (3.9 $\pm 0.002 \mathrm{ppm})$, besi $(14.9 \pm 0.001 \mathrm{ppm})$ dan zinc $(3.0 \pm 0.0001 \mathrm{ppm})$ terdeteksi pada $E$. cottonii. TPC pada E. cottonii ialah 3.40 $\pm 0.013 \mathrm{mg}$ GAE/g ekstrak. Nilai $\mathrm{IC}_{50}$ ekstrak E. cottonii pada DPPH adalah $38.82 \pm 0.99 \mathrm{mg} / \mathrm{ml}$.

Hasil uji aktivitas antioksidan dengan metode DPPH dan diekspresikan dengan nilai $\mathrm{IC}_{50}$. Didapatkan $\mathrm{IC}_{50}$ pada $E$. cottonii 72.49 ppm yang menyatakan aktivitas antioksidan yang tinggi. 


\begin{tabular}{|c|c|c|}
\hline $\begin{array}{l}\text { Nurjanah et } \\
\text { al, } 2017^{15}\end{array}$ & $\begin{array}{l}\text { Eucheuma } \\
\text { cottonii } \\
\text { diambil di } \\
\text { pantai Se- } \\
\text { rang, Banten }\end{array}$ & $\begin{array}{l}\text { Sampel } E \text {. cottonii diambil dalam keadaan } \\
\text { kering untuk mengurangi kerusakan kemu- } \\
\text { dian dicuci untuk dihilangkan kotoran dan } \\
\text { kandungan garam. Sampel dicacah }(100 \mathrm{~g}) \\
\text { kemudian ditaruh ke dalam Erlenmeyer } \\
\text { dengan pelarut. Laturan ekstrak disaring } \\
\text { dengan Whatman paper no, } 42 \text {. Filtrat } \\
\text { diuapkan dengan rotary evaporator pada } \\
\text { suhu } 40^{\circ} \mathrm{C} \text {. }\end{array}$ \\
\hline
\end{tabular}

Yanuarti et al, Eucheuma $2017^{10}$

$\begin{array}{ll}\text { cottonii di- } & \text { ambil dari } \\ \text { pantai } & \end{array}$

Lontar,

Serang-

Banten

Assaw et al, Gracilaria $2018^{16}$

Monteiro al, $2019^{18}$

sp. diambil dari Insitute of Marine Biotechnolog $\mathrm{y}$, Universiti Malaysia Terengganu yang didapat dari Johor Baru.

Neto et al, Gracilaria $2018^{17}$ sp. disediakan ALGA plus Lda, sebuah perusahaan yang memroduksi rumput laut untuk komersil makanan dan kosmetik

et Gracilaria sp. diambil dari Alga+ di Ilhavo, Portugal.
Ekstraksi rumput laut dengan metode maserasi bertingkat. 100 gr rumput laut dimaserasi dengan pelarut n-heksana, diaduk dengan shaker (150 rpm) selama $3 \times 24$ jam. Disaring dengan Whatman paper no,42 sehingga didapatkan filtrat dan residu. Residu dimaserasi dengan pelarut etil asetat, kemudian dimaserasi dengan pelarut metanol. Filtrat ketiga pelarut dievaporasi menggunakan rotary evaporator pada suhu $40^{\circ} \mathrm{C}$.

Digunakan dua ekstraksi, polisakarida dan metanol. Ekstraksi polisakarida menggunakan metode water-heat oleh Orosco. Ekstraksi metanol dengan cara dicampur perbandingan 10:1, direndam selama 48 jam dan dikocok pada suhu ruang. Ekstrak disaring dengan kapas dan dipekatkan dengan rotary evaporator tekanan vakum.

Gracilaria sp. diekstraksi dengan tiga prosedur berbeda dengan pelarut dan kondisi berikut: (i) air deionisasi pada suhu kamar (RTWE); (ii) 80\% etanol pada suhu kamar selama 24 jam (Eth80); (iii) 70\% aseton pada suhu kamar selama 24 jam (Acet70). Disentrifugasi pada 6000x g selama 10 menit kemudian disaring dengan filter gelas G4 dan dievaporasi memakai rotatory evaporator suhu $40^{\circ} \mathrm{C}$. Ekstrak di-bekukan, diliofilisasi dan disimpan pada suhu $4^{\circ} \mathrm{C}$.

Dilakukan ekstraksi polifenol. Sampel dicampur 1,5 ml campuran etanol:air atau metanol:air, vortex dan diinkubasi 30 menit dengan tiga kondisi: (i) agitasi orbital kontinyu dalam suhu kamar keadaan gelap (AG); (ii) agitasi horizontal kontran dalam shaker water bath suhu $40^{\circ} \mathrm{C}$ dalam gelap (AG40); (iii) pada sonication bath, suhu kamar, dalam gelap (UAE).
Komposisi kimia pada E. cottonii, ditemukan kandungan air $(77,27 \%)$, abu $(5,84 \%)$, protein $(2,39 \%)$, lemak $(0,12 \%)$ dan serat kasar $(0,67 \%)$. Kandungan vitamin E ditemukan sebesar 160,01 $\mathrm{mg} / \mathrm{L}$. Pada pemeriksaan aktivitas antioksidan, nilai $\mathrm{IC}_{50}$ pada ekstrak metanol E. cottonii ialah 105,04 mg/ml. E. cottonii juga mengandung komponen aktif flavonoid, phenol hydroquinone dan triterfenoid.

TPC pada E. cottonii dengan ekstrak metanol lebih tinggi (141,0 mg GAE/g) dibanding ekstrak etil asetat (134,3 mg GAE/g). Total flavonoid pada ekstrak metanol E. cottonii ditemukan sebesar $17,78 \mathrm{mg}$ QE/g dan ekstrak etil asetat sebesar 35,18 mg QE/g. Hasil uji aktivitas antioksidan $E$. cottoniii dengan pelarut metanol lebih besar $(23,15 \mu \mathrm{g} / \mathrm{ml})$ dibanding dengan pelarut etil asetat $(594,68 \mu \mathrm{g} / \mathrm{ml})$.

Uji aktivitas antioksidan dilakukan dengan rentang konsentrasi mulai 0-10 $\mathrm{mg} / \mathrm{ml}$ dengan kontrol positif Quecertin. Ekstrak polisakarida awalnya tidak ternilai hingga konsentrasi $2,5 \mathrm{mg} / \mathrm{ml}$ $(4,14 \% \pm 1,90), 5,0 \mathrm{mg} / \mathrm{ml}(6,13 \% \pm 0,66)$ dan $10 \mathrm{mg} / \mathrm{ml}(18,26 \% \pm 1,96)$. ekstraksi metanol pada $\mathrm{IC}_{50}$ adalah $5,6 \mathrm{mg} / \mathrm{ml}$.

TPC Gracilaria sp. rendah pada kondisi RTWE $(0,59 \pm 0,03 \mathrm{~g} / \mathrm{GAE} / 100 \mathrm{~g})$, ekstrak etanol 80\% $(0,49 \pm 0,03 \mathrm{~g} \mathrm{GAE} / 100 \mathrm{~g})$ dan ekstrak aseton $(0,54 \pm 0,01 \mathrm{~g} \mathrm{GAE} / 100 \mathrm{~g})$. Pada uji aktivitas antioksidan didapatkan 0,04 $\pm 0,01 \mathrm{~g}$ AAE/100 g pada ekstrak etanol dan $0.04 \pm 0.00 \mathrm{~g}$ AAE $/ 100 \mathrm{~g}$ pada ekstrak aseton, sedangkan pada kondisi RTWE tidak dapat dideteksi.

TPC pada Gracilaria sp. didapatkan memiliki nilai tertinggi pada perbandingan etanol:air 50:50. Didapatkan pada UAE tertinggi $(1,79 \pm 0,10 \mathrm{mg}$ GAE/g DW), diikuti AG $(1,76 \pm 0,06 \mathrm{mg} \mathrm{GAE} / \mathrm{g}$

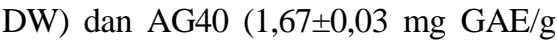
DW). Total flavonoid yang didapatkan dalam berbagai rasio dan ekstraksi cukup rendah. Dalam penelitian ini tidak ada ekstraksi yang dapat dikatakan memiliki metode yang efektif. Aktivitas antioksidan metode DPPH didapatkan cukup rendah. Nilai tertinggi didapatkan pada rasio metanol:air pada AG40 $(3,27 \pm 0,30$ $\mu$ mol Trolox/g DW), diikuti AG $(2,80 \pm 0,15 \mu \mathrm{mol}$ Trolox/g DW) dan UAE $(2,54 \pm 0,27 \mu \mathrm{mol}$ Trolox/g DW). 


\begin{tabular}{|c|c|c|c|}
\hline $\begin{array}{l}\text { Teo et al, } \\
2020_{19}\end{array}$ & $\begin{array}{l}\text { Eucheuma } \\
\text { cottonii } \\
\text { dikumpulkan } \\
\text { dari pemasok } \\
\text { resmi rumput } \\
\text { laut lokal di } \\
\text { pesisir Sem- } \\
\text { porna (Sabah, } \\
\text { Malaysia) }\end{array}$ & $\begin{array}{l}\text { Ekstraksi Aqueous (rumput laut dalam air) } \\
\text { merendam } 1 \text { gram pada } 100 \mathrm{ml} \text { air suling } \\
\text { dan penangas air } 70^{\circ} \mathrm{C} \text {. Disentrifugasi } \\
\text { kecepatan } 10.000 \times \mathrm{xg}, 10^{\circ} \mathrm{C} \text { selama } 10 \text { menit. } \\
\text { Hasil supernatan dipekatkan memakai } \\
\text { rotary evaporator suhu } 40^{\circ} \mathrm{C} \text { selama satu } \\
\text { jam. Dikeringkan dalam oven suhu } 50^{\circ} \mathrm{C} \text {. }\end{array}$ & $\begin{array}{l}\text { Uji aktivitas antioksidan menggunakan } \\
\text { kontrol positif asam askorbid. Hasil yang } \\
\text { didapatkan konsentrasi asam askorbid } \\
\mathrm{IC}_{50} \text { ialah } 0,09 \mathrm{mg} / \mathrm{ml} \text { dan konsentrasi } \\
\text { ekstraksi aqueous } E \text {, cottonii } \mathrm{IC}_{50} \text { ialah } \\
1,99 \mathrm{mg} / \mathrm{ml} \text {. Didapatkan aktivitas anti- } \\
\text { oksidan yang tinggi pada penelitian ini. }\end{array}$ \\
\hline
\end{tabular}

\section{BAHASAN}

Kandungan Total Fenol/Total phenolic content (TPC)

Pada penelitian Foon et al, ${ }^{11}$, uji kandungan total fenol didapatkan pada konvensional ekstraksi sebesar 8,71 $\pm 0,09 \mathrm{mg}$ GAE/g dan sohlext ekstraksi sebesar 9,04 $\pm 0,05 \mathrm{mg}$ GAE/g pada E. Cottonii.. Wardhani et al ${ }^{12}$ melakukan ekstraksi $E$. cottonii dengan ultrasonik dan membagi ekstraksi dalam berbagai suhu $\left(35^{\circ} \mathrm{C}-60^{\circ} \mathrm{C}\right)$, waktu (10-45 menit) dan rasio cair-padat (3:1 - 10:1). Didapatkan TPC tertinggi pada suhu $55^{\circ} \mathrm{C}$ (3.88 mg GAE/g dry weight), dalam ekstraksi selama 35 menit $(4,2 \mathrm{mg}$ GAE/g dry weight) dan pada rasio pelarut-padat $3: 1$ (4,440 mg GAE/g dry weight). Hasil penelitian yang dilakukan Chang dan Teo ${ }^{13}$ mendapatkan total phenolic content ekstrak

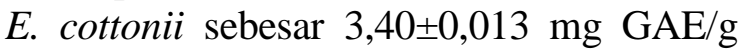
yang menunjukkan kurangnya total fenol pada E. cottonii. Pada penelitian Yanuarti et al, ${ }^{10}$ E. cottonii dibagi dua dengan pelarut metanol dan pelarut etil asetat dan didapatkan TPC dengan ekstrak metanol lebih tinggi (141,0 mg GAE/g) dibanding ekstrak etil asetat $(134,3 \mathrm{mg}$ GAE/g). Pada penelitian oleh Neto et al, ${ }^{17}$ Gracilaria sp. dilakukan dengan tiga prosedur ekstraksi yang berbeda dan didapatkan nilai TPC yang rendah pada ketiga prosedur ekstraksi tersebut. Ditemukan hasil pada RTWE $(0,59 \pm 0,03 \mathrm{~g} /$ GAE/100 g), ekstrak etanol $80 \%(0,49 \pm 0,03$ $\mathrm{g} \mathrm{GAE} / 100 \mathrm{~g})$, dan ekstrak aseton $(0,54 \pm 0,01$ g GAE/100 g. TPC pada Gracilaria sp. yang didapatkan pada penelitian Monteiro et $\mathrm{al}^{18}$ memiliki nilai tertinggi pada perbandingan etanol:air 50:50. Didapatkan pada UAE tertinggi $(1,79 \pm 0,10 \mathrm{mg}$ GAE/g DW), diikuti AG (1,76 $\pm 0,06 \mathrm{mg}$ GAE/g DW), dan AG40 $(1,67 \pm 0,03 \mathrm{mg}$ GAE/g DW).
Sebagian besar studi yang meneliti Eucheuma cottonii pada penelitian ini mendapatkan hasil yang kurang lebih sama yaitu kurangnya kandungan kadar fenolik (TPC) pada rumput laut merah jenis $E$. Cottonii. ${ }^{11-13}$ Hal ini dapat dikarenakan habitat $E$. cottonii pada daerah yang kurang mendapat sinar matahari. Peinado et $\mathrm{al}^{20}$ menyebutkan bahwa terdapat korelasi antara paparan sinar matahari dan tingginya kandungan kadar fenolik. Hasil ini sejalan dengan penelitian yang dilakukan Matanjun et $\mathrm{al}^{21}$ yang menilai kandungan fenolik pada delapan spesies rumput laut di Kalimantan Utara dan mendapatkan hasil yang jelas bahwa kandungan total fenolik pada rumput laut merah lebih rendah dibandingkan dua jenis rumput laut lainnya. Sebaliknya, Yanuarti et al $^{10}$ mendapatkan kadar fenolik yang tinggi pada $E$. cottonii pada ekstrak metanol (141 mg GAE/g) dan etil asetat (134,33 mg GAE/g). Semua studi yang meneliti Gracilaria sp. pada penelitian ini mendapatkan hasil kandungan total fenolik yang rendah. ${ }^{16-18}$

\section{Total Flavonoid}

Pada penelitian Yanuarti et a ${ }^{10}$ dilakukan uji total flavonoid dan ditemukan $E$. cottonii dengan pelarut metanol mendapatkan total flavonoid sebesar 17,78 $\mathrm{mg}$ QE/g dan dengan pelarut etil asetat sebesar $35,18 \mathrm{mg} \mathrm{QE} / \mathrm{g}$. Untuk analisis fitokimia, $E$. cottonii ditemukan mengandung flavonoid, phenol hydroquinone, dan triterfenoid yang dilaporkan pada penelitian Nurjanah et al. ${ }^{15}$ Pada total flavonoid Gracilaria sp. yang didapatkan oleh Yanuarti et al ${ }^{10}$ dilakukan uji total flavonoid dan ditemukan E. cottonii dengan pelarut metanol mendapatkan sebesar 17,78 mg QE/g dan dengan pelarut 
etil asetat cukup rendah. Monteiro et al ${ }^{18}$ melakukan penelitian dengan mencampur sampel dengan 1,5 $\mathrm{ml}$ campuran etanol:air (E80:20, E50:50) atau metanol:air (M80:20, M50:50) dengan tiga metode berbeda. Dalam berbagai rasio dan metode didapat-kan kadar total flavonoid yang rendah dengan nilai tertinggi pada rasio etanol:air (E80:20) pada metode UAE $(0.85 \pm 0.09 \mathrm{mg} \mathrm{CT} / \mathrm{g})$.

Pada Eucheuma cottonii didapatkan total flavonoid yang cukup tinggi sehingga ekstrak metanol pada $E$. cottonii dapat berperan sebagai antioksidan. Total flavonoid yang didapatkan lebih tinggi jika dibandingkan dengan total flavonoid pada ekstrak metanol S. wightii (2.02 $\mathrm{mg} \mathrm{QE} / \mathrm{g}){ }^{22}$ sedangkan pada Gracilaria sp. didapatkan rendahnya total flavonoid dalam ekstraksi dengan berbagai rasio campuran etanol:air atau metanol:air dan berbagai metode. ${ }^{18}$ Flavonoid merupakan golongan terbesar yang terdiri dari beberapa struktur berbeda sehingga memiliki tingkat kelarutan berbeda pula, tetapi umumnya senyawa flavonoid larut dalam pelarut semi polar hingga polar. ${ }^{10}$ Karena tingkat flavonoid yang rendah pada mikroalga, kontribusinya sebagai antioksidan secara keseluruhan dinilai kecil. ${ }^{23}$

\section{Aktivitas Antioksidan}

Foon et $\mathrm{al}^{11}$ melakukan dua metode ekstraksi (konvensional dan sohxlet) pada $E$. cottonii dan mendapatkan keduanya memiliki aktivitas antioksidan yang tinggi. Pada sohxlet ekstraksi didapatkan aktivitas antioksidan sedikit lebih tinggi $(31,44 \pm 0,08$ $\mathrm{mg} / \mathrm{ml}$ ) dibanding pada konvensional ekstraksi $(32,74 \pm 0,16 \mathrm{mg} / \mathrm{ml})$ walaupun tidak berbeda secara bermakna. Penelitian Wardhani et al ${ }^{12}$ dengan ekstraksi ultrasonik mendapatkan $E$. cottonii dengan rasio pelarut-padat 3:1 memiliki aktivitas antioksidan yang tinggi yaitu 69\%. Efek radical scavenging DPPH pada penelitian Chang dan $\mathrm{Teo}^{13}$ dipresentasikan dalam $\mathrm{IC}_{50}$ yaitu nilai $\mathrm{IC}_{50}$ pada ekstrak $E$. cottonii sebesar $38.82 \pm 0.99 \mathrm{mg} / \mathrm{ml}$. Penelitian Muawanah et $\mathrm{al}^{14}$ mendapatkan hasil uji aktivitas antioksidan pada E. cottonii yang kuat $(72,49$ ppm). Pada penelitian Nurjanah et a ${ }^{15}$ nilai $\mathrm{IC}_{50}$ ekstrak E. cottonii didapatkan 105,04 $\mathrm{mg} / \mathrm{ml}$. Pada uji aktivitas antioksidan yang dilakukan Yanuarti et al ${ }^{10}$ dengan metode DPPH dan diekspresikan menggunakan $\mathrm{IC}_{50}$ didapatkan E. cottonii dengan pelarut metanol lebih besar $(23,15 \mu \mathrm{g} / \mathrm{ml})$ dibanding dengan pelarut etil asetat $(594,68 \mu \mathrm{g} / \mathrm{ml})$. Assaw et al ${ }^{16}$ meneliti Gracilaria sp. dengan menggunakan ekstraksi polisakarida dan ekstraksi metanol. Pada pengujian ekstrak polisakarida awalnya tidak ternilai hingga konsentrasi mencapai $2,5 \mathrm{mg} / \mathrm{ml}(4,14 \% \pm$ $1,90), 5,0 \mathrm{mg} / \mathrm{ml}(6,13 \% \pm 0,66)$, dan 10 $\mathrm{mg} / \mathrm{ml} \quad(18,26 \% \pm 1,96)$ sedangkan pada ekstraksi metanol didapatkan nilai $\mathrm{IC}_{50}$ ialah $5,6 \mathrm{mg} / \mathrm{ml}$ (sangat kuat). Neto et al ${ }^{17}$ melakukan penelitian pada Gracilaria Sp. dengan nilai uji aktivitas antioksidan didapatkan $0,04 \pm 0,01 \mathrm{~g}$ AAE/100 g pada ekstrak etanol dan 0,04 $\pm 0,00 \mathrm{~g}$ AAE/100 g pada ekstrak aseton. Pada penelitian Monteiro et $\mathrm{al}^{18}$ didapatkan nilai tertinggi aktivitas antioksidan pada rasio metanol:air pada AG40 (3,27 $\pm 0,30 \mu \mathrm{mol}$ Trolox/g DW), diikuti AG $(2,80 \pm 0,15 \mu \mathrm{mol}$ Trolox/g DW) dan UAE $(2,54 \pm 0,27 \mu$ mol Trolox/g DW). Nilai tersebut dinyatakan cukup rendah untuk aktivitas antioksidan dan bila dihubungkan dengan kadar TPC pada penelitian, dinilai rumput laut Gracilaria sp. memiliki aktivitas antioksidan yang cukup rendah. Teo et al ${ }^{19}$ menilai kandungan aktivitas antioksidan E. cottonii pada pengobatan luka tikus dan didapatkan $\mathrm{IC}_{50}$ sebesar 1,99 $\mathrm{mg} / \mathrm{ml}$. Uji aktivitas antioksidan pada penelitiannya menggunakan kontrol positif asam askorbat dengan nilai $\mathrm{IC}_{50} 0,99 \mathrm{mg} / \mathrm{ml}$. Asam askorbat digunakan sebagai standar persentase aktivitas antioksidan yang tinggi. Simpulan penelitian ialah aktivitas antioksidan yang didapatkan pada E. cottonii sangat kuat.

Aktivitas antioksidan yang dilakukan pada literatur menggunakan metode DPPH dengan variasi kontrol positif dan ekspresi. Sebagian besar penelitian pada E. cottonii dan Gracilaria sp. didapatkan memiliki IC $_{50}$ dan persentase yang tinggi. Hal ini menyatakan bahwa kedua jenis rumput laut merah ini memiliki aktivitas antioksidan tinggi. Pada penelitian lain disebutkan bahwa terdapat korelasi bermakna antara peningkatan akti- 
vitas antioksidan dengan kandungan total fenolik yang dimiliki mikroalga. ${ }^{23}$ Hal ini masih kontradiktif dikarenakan beberapa penulis menyebutkan bahwa kandungan fenolik memiliki kontribusi besar terhadap aktivitas antioksidan, ${ }^{24}$ sedangkan penulis lain menyebutkan bahwa karotenoid yang berperan penting. ${ }^{25}$

\section{SIMPULAN}

Rumput laut merah memiliki kandungan antioksidan yang dapat dinilai dengan melihat kadar total phenolic content (TPC). Senyawa yang banyak ditemukan ialah fenolik dan flavonoid. yang memiliki aktivitas anti-oksidan tinggi Aktivitas antioksidan rumput laut merah (Rhodophyta) yang ditinjau berdasarkan kadar IC50 tergolong tinggi.

\section{Konflik Kepentingan}

Penulis menyatakan tidak terdapat konflik kepentingan dalam studi ini.

\section{DAFTAR PUSTAKA}

1. Parwata MOA. Bahan Ajar Antioksidan. Kim Terap Progr Pascasarj Univ Udayana, 2016;(April):1-54

2. Amarowicz R, Naczk M, Shahidi F. Antioxidant activity of crude tannins of canola and rapeseed hulls. JAOCS. 2000;77:957-61.

3. Kurniawati I, Maftuch, Hariati AM. Penentuan pelarut dan lama ekstraksi terbaik pada teknik maserasi Gracilaria sp. serta pengaruhnya terhadap kadar air dan rendemen. Jurnal Ilmu Perikanan. 2016; 7(2):72-77.

4. Santosa GW. Budidaya rumput laut. Program Community College Industri Kelautan dan Perikanan. Universitas Diponegoro. Semarang. 2013.

5. Surono A. Profil rumput laut Indonesia. Jakarta: Direktorat Jenderal Perikanan Budidaya. Departemen Kelautan dan Perikanan, 2004.

6. Annisaqois M, Gerung GS, Wullur S, Sumilat DA, Wagey BT, Mandagi SV. Molecular analysis of DNA red algae (Rhodophyta) Kappaphycus sp. Jurnal Pesisir dan Laut Tropis. 2018;1(1):107-12.

7. Kelman D, Posner EK, McDermid KJ, Tabandera NK, Wright PR, Wright AD.
Antioxidant activity of Hawaiian marine algae. Marine Drugs. 2012;10:403-16.

8. Selim SA. Antimicrobial, antiplasmid and cytotoxicity potentials of marine algae Halimeda opuntia and Sarconema filiforme collected from red sea coast. World Academy of Science. Engineering and Technology Journal. 2012; 2(1):1154-9.

9. Amaranggana L, Wathoni N. Manfaat alga merah (Rhodophyta) sebagai sumber obat dari bahan alam. Farmasetika. 2017;2(1):16.

10. Yanuarti R, Nurjanah, Effionora A, Hidayat T. Profil fenolik dan aktivitas antioksidan dari ekstrak rumput laut Turbinaria conoides dan Eucheuma cottonii. Jurnal Pengolahan Hasil Perikanan Indonesia (JPHPI). 2017;20(2):230-7.

11. Foon TS, Ai LA, Kuppusamy P, Yusoff MM, Govindan N. Studies on in-vitro antioxidant activity of marine edible seaweeds from the east coastal region of Peninsular Malaysia using different extraction methods. J Coast Life Med. 2013;1(3):193-8.

12. Wardhani DH, Sari DK, Prasetyaningrum A. Ultrasonic-assisted extraction of antioxidant phenolic coumpounds from Eucheuma Cottonii. Reaktor. 2013; 14(4):291-7.

13. Chang VS, Teo SS. Evaluation of heavy metal, antioxidant and anti-tyrosinase activities of red seaweed (Eucheuma cottonii). Int Food Res J. 2016;23(6):2370-4.

14. Muawanah, Ahmad A, Natsir H. Antioxidant activity and toxicity polysaccharide extract from red algae Eucheuma spinosum and Eucheuma cottonii. Mar Chim Acta. 2016;17(2):15-23.

15. Nurjanah, Nurilmala M, Anwar E, Luthfiyana $\mathrm{N}$, Hidayat $\mathrm{T}$. Identification of bioactive compounds of seaweed sargassum sp. and eucheuma cottonii doty as a raw sunscreen cream. Proc Pakistan Acad Sci Part B. 2017;54(4):311-8.

16. Assaw S, Rosli NL, Azmi NAM, Mazlan NW, Ismail N. Antioxidant and antibacterial activities of polysaccharides and methanolic crude extracts of local edible red seaweed Gracilaria sp. Malaysian Appl Biol. 2018;47(4):135-44.

17. Neto RT, Marçal C, Queirós AS, Abreu H, Silva AMS, Cardoso SM. Screening of ulva rigida, gracilaria sp., fucus vesicu- 
120 Medical Scope Journal (MSJ), Volume 3, Nomor 1, Juli-Desember 2021, hlm. 113-120

losus and saccharina latissima as functional ingredients. Int $\mathrm{J}$ Mol Sci. 2018;19(10):2987.

18. Monteiro M, Santos RA, Iglesias P, Couto A, Serra CR, Gouvinhas I, et al. Effect of extraction method and solvent system on the phenolic content and antioxidant activity of selected macro- and microalgae extracts. J Appl Phycol. 2020;32(1):349-62.

19. Teo BSX, Gan RY, Abdul Aziz S, Sirirak T, Mohd Asmani MF, Yusuf E. In vitro evaluation of antioxidant and antibacterial activities of Eucheuma cottonii extract and its in vivo evaluation of the wound-healing activity in mice. J Cosmet Dermatol. 2021;20(3):9931001.

20. Peinado J, López de Lerma N, Peralbo-Molina A, Priego-Capote F, de Castro C, McDonagh B. Sunlight exposure increases the phenolic content in postharvested white grapes: An evaluation of their antioxidant activity in Saccharomyces cerevisiae. J Funct Foods. 2013;5(4): 1566-75.

21. Matanjun P, Mohamed S, Mustapha NM, Muhammad K, Ming CH. Antioxidant activities and phenolics content of eight species of seaweeds from north Borneo. J Appl Phycol. 2008;20(4):367-73.

22. Meenakshi S, Gnanambigai DM, Mozhi ST, Arumugam M, Balasubramanian $\mathrm{T}$. Total flavanoid and in vitro antioxidant activity of two seaweeds of Rameshwaram Coast. Glob J Pharmacol. 2009; 3(2):59-62.

23. Gouvinhas I, Machado J, Gomes S, Lopes J, Martins-Lopes P, Barros AIRNA. Phenolic composition and antioxidant activity of monovarietal and commercial portuguese olive oils. JAOCS, J Am Oil Chem Soc. 2014;91(7):1197-203.

24. Farasat M, Khavari-Nejad RA, Nabavi SMB, Namjooyan F. Antioxidant activity, total phenolics and flavonoid contents of some edible green seaweeds from northern coasts of the Persian gulf. Iran J Pharm Res. 2014;13(1):163-70.

25. Goh S-H, Yusoff FM, Loh SP. A comparison of the antioxidant properties and total phenolic content in a diatom, Chaetoceros sp. and a Green Microalga, Nannochloropsis sp. J Agric Sci. 2010; 2(3):123-7. 